\title{
Ultrastructural and biomolecular detection of Rickettsiales-like organisms in tissues of rainbow trout with Red Mark Syndrome
}

\author{
M Galeotti ${ }^{1}$, M Manzano ${ }^{1}$, P Beraldo ${ }^{1}$, C Bulfon ${ }^{1}$, G Rossi $^{2}$, D Volpatti ${ }^{1}$ and G E Magi ${ }^{2}$ \\ 1 Department of Agricultural, Food, Environmental and Animal Science, Veterinary Pathology Section and Micro- \\ biology Section, University of Udine, Udine, Italy \\ 2 School of Biosciences and Veterinary Medicine, University of Camerino, Matelica, Italy
}

\section{Abstract}

Red mark syndrome (RMS) and US strawberry disease (US SD) are skin disorders affecting rainbow trout farmed in Europe and USA. The disease etiology has not yet been established. In spite of specific investigations, identifying Rickettsia-like organism (RLO)- and Midichloria-like organism (MLO)-related DNA in affected individuals, these pathogens have never been observed. We performed histological, ultrastructural and biomolecular analysis on skin and spleen samples of trout with RMS. Examination by TEM revealed the presence of intracytoplasmic microorganisms resembling Rickettsiales within macrophages, fibroblasts and erythrocytes. The microorganisms were oval or short rod shaped (400-800 nm in length and 100-200 nm in width) and often showed a cell wall similar to Gram-negative bacteria. PCR analysis for Rickettsiales supported these findings: 53\% of affected trout were positive by both PCR and TEM The primers RiFCfw-RiFCrev were used to anneal both the RLO 16S DNA sequence and the MLO 16S DNA sequence. For this reason, and in agreement with previous studies confirming the presence of Rickettsiales-related DNA in trout with RMS, we assume that TEM detected microorganisms morphologically consistent with bacteria belonging to Rickettsiales order and

Correspondence M Galeotti, Department of Agricultural, Food, Environmental and Animal Science, Veterinary Pathology Section, University of Udine, Italy (e-mail: marco.galeotti@uniud.it) could be considered as possible causative agents of RMS.

Keywords: PCR, rainbow trout, red mark syndrome, Rickettsiales-like organisms, TEM.

\section{Introduction}

Red mark syndrome (RMS) is a skin disorder affecting farmed rainbow trout (Oncorhynchus mykiss) that was reported in the U.K. (Ferguson et al. 2006; Verner-Jeffreys et al. 2006, 2008; Noguera 2008; Oidtmann \& Noguera 2008). Cases of the disease were subsequently recorded in Finland (Bruno et al. 2007), Austria and Switzerland (Schmidt-Posthaus et al. 2009), Italy (Galeotti et al. 2011) and more recently in Turkey (Kubilay et al. 2014) and Iran (Sasani et al. 2016). The authors strongly correlate European RMS with two similar rainbow trout diseases reported in the USA, namely US strawberry disease (US SD) and US Rash (Olson et al. 1985; LaPatra et al. 1994; Lloyd et al. 2008) that have been well characterized according to the criteria of Oidtmann et al. 2013. Moreover, RMS shares some similarities with a warm water strawberry disease (WWSD), previously described in Europe (Fleury, Vuillaume \& Sochon 1985; St-Hilaire \& Jeffery 2004) even if RMS displays peculiar features related to water temperature and antibiotic responsiveness. RMS may spread from unit to unit within a single farm or among different farms (Verner-Jeffreys et al. 2006, 2008). The transmissible nature of the disease has been demonstrated 
and there are etiological speculations regarding the possible role of an infectious agent (Verner-Jeffreys et al. 2008). As potential pathogen, Ferguson et al. (2006) suggested Flavobacterium psychrophilum, and more recently, a Rickettsia-like organism (RLO) was proposed for US SD (Lloyd et al. 2008) and for RMS (Metselaar et al. 2010). Splenic impression smears revealed morula-like structures (Rickettsia-like organisms) in the cytoplasm of spleen macrophages of RMS-affected rainbow trout (Galeotti et al. 2013a). Recently, the positivity for Midichloria-like organism (MLO)-related DNA in trout affected by RMS in Scotland has been described (Cafiso et al. 2015). In spite of these investigations identifying RLO/ MLO-related DNA in tissues of RMS and US SD-affected individuals, these pathogens have never been observed in histological and ultrastructural samples. This study was aimed at providing novel insights into the potential association of the disease with a transmissible infectious agent, by taking a histological, ultrastructural and biomolecular approach. Here, we present the ultrastructural and molecular evidence for the presence of Rickettsiales-like organisms in the macrophages, fibroblasts and erythrocytes populations of RMS-affected rainbow trout in Italy.

\section{Materials and methods}

\section{Description of outbreaks and sampling}

This study considered two rainbow trout farms located in Northern Italy, periodically affected by RMS episodes. They were surveyed throughout the spring-autumn period of 2013 and 2014, when the water temperature ranged between $9^{\circ}$ and $10{ }^{\circ} \mathrm{C}$. The percentage of affected fish in the farms was $10-15 \%$, and their mean size was $500 \mathrm{~g}$. They did not show other signs of disease except those ascribable to RMS (Oidtmann et al. 2013), and mortality was absent. Eight symptomatic fish from farm $\mathrm{A}$ and nine from farm $\mathrm{B}$ were sampled among those showing severe skin lesions and sacrificed for the investigation. They were submitted to histological, ultrastructural and biomolecular analysis. For comparison purposes, normal skin and underlying muscle tissues, as well as spleens, were also collected from five healthy fish from the aquaculture unit of the University of Udine (Pagnacco), which has never reported cases of RMS and is presumptively a RMS-free facility.

\section{Histology}

Samples of skin with RMS lesions, muscle and spleen of the 17 trout displaying RMS gross lesions, and the five healthy trout, were fixed in $4 \%$ neutral-buffered formaldehyde for $48 \mathrm{~h}$ and Bouin's solution at $4{ }^{\circ} \mathrm{C}$ overnight. After fixation, samples were equilibrated at room temperature and processed by an automatic histoprocessor (TISBE tissue processor, Diapath) to embed the tissue in paraffin (ParaplastPlus, Diapath). Serial $5-\mu \mathrm{m}$ sections were obtained by a programmable microtome (Reichert-Jung 2050) and then stained with haematoxylin-eosin, Grocott, Giemsa, Brown-Hopps and Macchiavello. The specimens were examined by light microscope (Leica DMRB), and digital images were acquired by a Nikon system.

\section{Transmission electron microscopy}

Samples (about $1 \mathrm{~mm}$ ) of skin/muscle and spleen of 17 RMS and five RMS-free fish were fixed for $3 \mathrm{~h}$ in $2.5 \%$ glutaraldehyde in $0.1 \mathrm{M}$ cacodylate buffer at $\mathrm{pH}$ 7.2. After rinsing in the same buffer, samples were post-fixed for $1 \mathrm{~h}$ in $1 \%$ osmium tetroxide in $0.1 \mathrm{~m}$ cacodylate buffer at $\mathrm{pH}$ 7.2, dehydrated in a graded sequence of alcohols and embedded in Durcupan AcM resin. Semithin sections were stained with toluidine blue and examined by light microscopy to locate skin areas characterized by severe inflammation. Selected semithin sections from RMS-free fish including the matching skin layers were similarly processed. Ultrathin sections were cut from each specimen and stained with uranyl acetate and lead citrate. Ultrastructural observation was performed using a Zeiss EM 109 transmission electron microscope (TEM) (Carl Zeiss AG) operated at $80 \mathrm{kV}$.

\section{Molecular biology}

Samples of skin/muscle with lesions and spleen of 17 symptomatic trout, and skin/muscle and spleen without lesions of five RMS-free trout were immediately frozen in liquid nitrogen $\left(-196{ }^{\circ} \mathrm{C}\right)$ and cryopreserved at $-80^{\circ} \mathrm{C}$ before the analysis. The DNA was extracted from spleen (sp) (1 g) and skin (sk) (1.5 g), using Wizard Genomic DNA Purification kit (Promega) following the animal tissue mouse and 
liver brain protocol. The DNA was then stored at $-20{ }^{\circ} \mathrm{C}$ for further analysis.

PCR assays for the detection of Rickettsiales sequence. The first step of a nested PCR assay for the detection of RLO 16S rRNA in RMSaffected and not affected tissues (control fish) was performed using the primers RLO1 and RLO2 (Lloyd et al. 2008) with some modifications. An aliquot of $49 \mu \mathrm{L}$ of the master mix instead of $24 \mu \mathrm{L}$ was used, including water, containing the following reaction mixture for each sample: $1.25 \mathrm{U}$ of $\mathrm{GoTaq}^{\circledR}$ DNA Polymerase (Promega) instead of $0.5 \mathrm{U}$ of Taq polymerase (Fisher Scientific), $1 \mathrm{X}$ PCR buffer, $\mathrm{MgCl}_{2}$ concentration was increased from $1 \mathrm{~mm}$ to $1.5 \mathrm{~mm}$, each dNTPs was increased from $0.1 \mathrm{~mm}$ to $0.2 \mathrm{~mm}$ and each primer was reduced from $0.4 \mathrm{~mm}$ to $0.2 \mu \mathrm{M}$.

The mix was distributed in each tube and added with $1 \mu \mathrm{L}$ of template DNA (250 ng $\mu \mathrm{L}^{-1}$ ) added to obtain a final volume of $50 \mu \mathrm{L}$. The amplification protocol: the time of denaturation at $95{ }^{\circ} \mathrm{C}$ was increased from 2 to $5 \mathrm{~min}, 35$ cycles of $95^{\circ} \mathrm{C}$ for $30 \mathrm{~s}$, the annealing temperature was increased from $57^{\circ} \mathrm{C}$ to $69^{\circ} \mathrm{C}$ for $30 \mathrm{~s}, 72^{\circ} \mathrm{C}$ for $30 \mathrm{~s}$ instead of $60 \mathrm{~s}$ and a final extension at $72{ }^{\circ} \mathrm{C}$ for $10 \mathrm{~min}$ in a thermal cycler (DNA Engine Dyad peltier Thermal Cycler, Bio-Rad). For each PCR, water has been used as a blank (negative control) to verify that no contaminations were present during the amplification step.

To increase the specificity and the sensitivity of the protocol, a second PCR assay of the nested PCR was developed by designing a new primer pair, RiFCfw 5'-AAGGCAACGATCTTTAGTT GG-3' and RiFCrev 5'- CCGTCATTATCTT CCCCACT- $3^{\prime}$, annealing within the amplicon obtained by the first step using the primers RLO1 and RLO2. The RiFCfw and RiFCrev primers anneal both MLO and RLO sequences. After the alignment of the sequences retrieved from GenBank using the 'Multiple sequence alignment with hierarchical clustering' function (Corpet 1988), and tested with Blast (http://blast.ncbi.nlm.nih.gov/ Blast.cgi?CMD=Web\&PAGE_TYPE=BlastHome; Blast.h), the primers were designed and synthetized. The amplification was obtained using $1 \mu \mathrm{L}$ of the first step as template following the protocol: $95^{\circ} \mathrm{C}$ denaturation for $5 \mathrm{~min}, 35$ cycles of $95^{\circ} \mathrm{C}$ for 45 s, $54{ }^{\circ} \mathrm{C}$ for $45 \mathrm{~s}, 72{ }^{\circ} \mathrm{C}$ for $45 \mathrm{~s}$ and a final extension at $72{ }^{\circ} \mathrm{C}$ for $7 \mathrm{~min}$.

\section{Results}

\section{Case studies and necropsy findings}

The gross skin lesions included small, flat, pale red areas, or pink spots, characterized by the absence of desquamation and rare haemorrhages, or protruding areas with great extension, a round/ oval shape, covered by serous/fibrin exudate, displaying various intensity of reddening, haemorrhage and slight desquamation (Fig. 1). In some individuals, larger, slightly raised lesions with variable degrees of redness, evident desquamation and central ulceration were observed. Necropsy included the examination of internal organs and did not reveal further lesions. According to the standardized method proposed for the description of rainbow trout skin disorders of uncertain aetiology (including the RMS cases definitions) (Oidtmann et al. 2013), the authors asserted that the macroscopic signs were ascribable to RMS.

\section{Histology}

The skin lesions observed in all specimens were characterized by an inflammation involving all the layers from epidermis to subcutis, including the underlying muscular tissue (Fig. 2). The epidermis was often present, or partially missing. In some specimens, a moderate intra-epidermal necrosis was detectable and this layer was also oedematous (with peculiar thorn shaped cellular expansions). The stratum spongiosus (SS) of the derma was affected by a mild or severe infiltration of lymphocytes and monocytes, and occasionally recruited neutrophil granulocytes. Scales and their pockets were severely affected by an inflammatory reaction, showing a strong infiltration of lymphocytes and monocytes/macrophages within the pockets, particularly below the scales. The stratum compactum (SC) was thickened and slightly infiltrated by lymphocytes/macrophages, but still maintaining its structure. The subcutis was heavily infiltrated by lymphocytes, plasma cells and macrophages. A slight fibroplasia was also detectable. The underlying muscular tissue appeared often subjected to moderate/severe cellular 

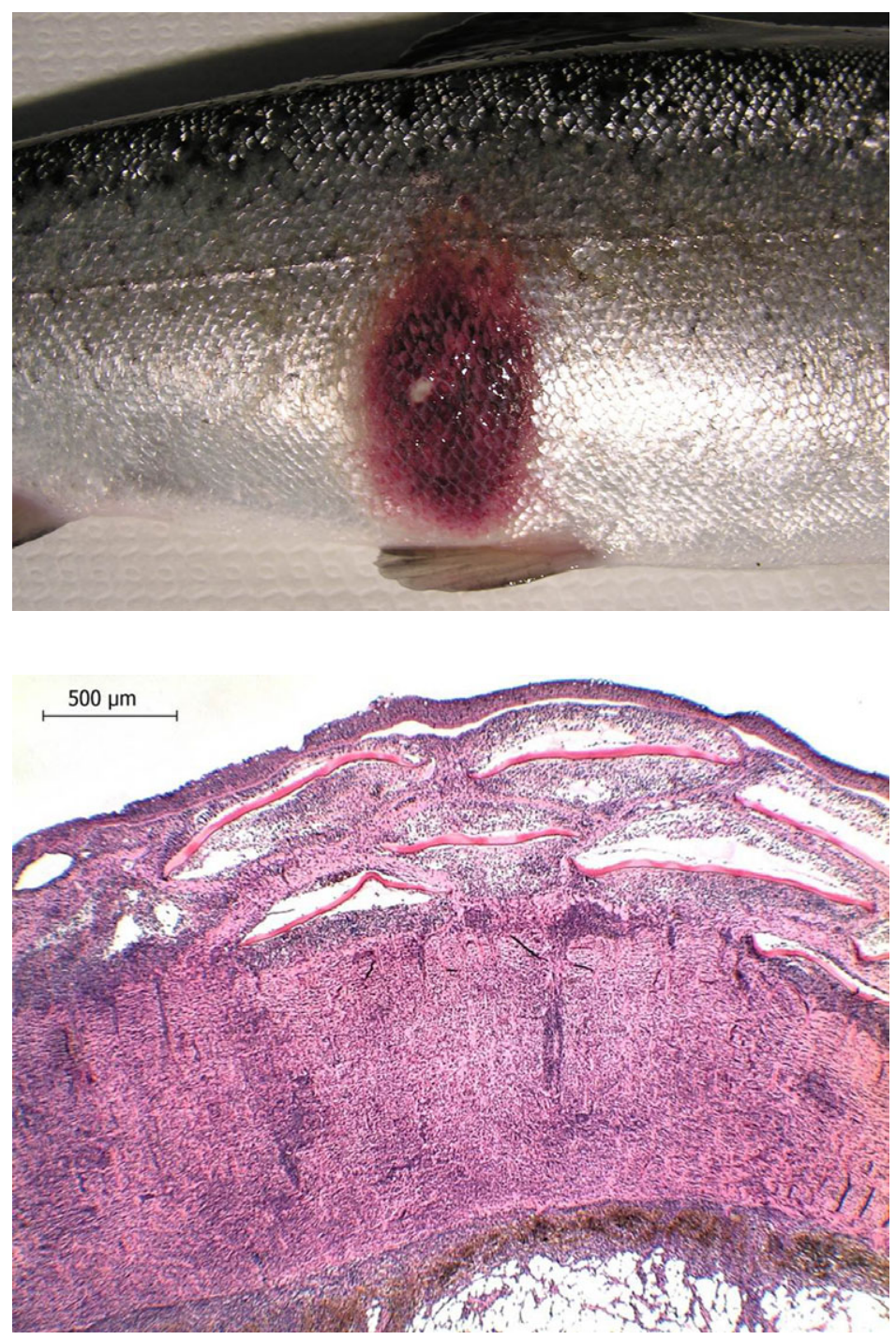

Figure 1 Typical gross skin lesion including a large, flat, red area, oval shaped, displaying haemorrhage and slight desquamation. [Colour figure can be viewed at wileyonlinelibrary.com].

Figure 2 Skin lesion characterized by inflammation involving all layers from epidermis to subcutis, including the underlying muscular tissue. The stratum spongiosus of the derma is affected by a severe infiltration of lymphocytes and monocytes. Scales and their pockets are severely affected by infiltration of lymphocytes and monocytes/macrophages both internal to the pockets and below the scales. The stratum compactum is thickened and heavily infiltrated by lymphocytes/macrophages. The subcutis is heavily infiltrated by lymphocytes, plasma cells and macrophages (H\&E). [Colour figure can be viewed at wileyonlinelibrary.com]. infiltration of lymphocytes, plasma cells and macrophages. These cells were mainly localized in muscle areas underlying the infiltrated subcutis and tended to penetrate trough the myosepta. Grocott, Giemsa, Brown-Hopps and Macchiavello staining did not allow the detection of microorganisms in the tissues under examinations. In the five RMS-free trout, no lesions and microorganisms were observed.

\section{Transmission electron microscopy}

From the skin and/or spleen specimens of 10 RMS trout (59\%), in numerous fibroblasts and in a variable number of macrophages, neutrophils and erythrocytes, intracytoplasmic microorganisms were present (Table 1). In eight of 10 trout, the number of cells containing the microorganisms was always more than five in the skin or spleen tissue samples under investigation. The microorganisms appeared as oval or short rod shaped, displaying a size ranging from 400 to $800 \mathrm{~nm}$ in length and 100 to $200 \mathrm{~nm}$ in width with a finely granular electron-dense cytoplasm (Figs 3-9). Often, the microorganisms had a distinct thin cell wall of about $10 \mathrm{~nm}$, arranged in a distinct trilaminar structure typical of Gram-negative bacteria, composed by an outer and an inner membrane (cellular envelope) and a cytoplasmic membrane (Figs 4, 6 \& 7). Also a thread-like structure located at one pole of the body was present beneath the cell membrane (Fig. 4) and a 
Table 1 Transmission electron microscopy observations for the presence of intracellular Rickettsiales-like organisms in trout with RMS. Criteria for scoring positivity was considered as follows: a + was assigned when intracellular bacteria were observed in one to five cells/sample, a ++ if 5 to 10 cells/sample showed intracellular bacteria and a +++ when more of 10 cells/sample were positive

\begin{tabular}{|c|c|c|c|}
\hline Trout no. & $\begin{array}{l}\text { Rickettsiales-like } \\
\text { organisms } \\
\text { positive organ }\end{array}$ & $\begin{array}{l}\text { Rickettsiales-like } \\
\text { organisms } \\
\text { positive cells }\end{array}$ & $\begin{array}{l}\text { Positivity } \\
\text { score }\end{array}$ \\
\hline 1 & Skin & $\begin{array}{c}\text { Macrophages, } \\
\text { fibroblasts }\end{array}$ & + \\
\hline 2 & Skin, spleen & $\begin{array}{l}\text { Macrophage, } \\
\text { fibroblasts, } \\
\text { erythrocytes }\end{array}$ & ++ \\
\hline 3 & Spleen & $\begin{array}{c}\text { Macrophages, } \\
\text { erythrocytes }\end{array}$ & +++ \\
\hline 4 & Skin, spleen & $\begin{array}{c}\text { Macrophages, } \\
\text { fibroblasts }\end{array}$ & +++ \\
\hline 5 & Skin & $\begin{array}{l}\text { Macrophages, } \\
\text { fibroblasts }\end{array}$ & ++ \\
\hline 6 & Spleen & $\begin{array}{c}\text { Macrophages, } \\
\text { erythrocytes }\end{array}$ & ++ \\
\hline 7 & Skin & Fibroblasts & ++ \\
\hline 8 & Negative & - & - \\
\hline 9 & Negative & - & - \\
\hline 10 & Negative & - & - \\
\hline 11 & Negative & - & - \\
\hline 12 & Negative & - & - \\
\hline 13 & Skin, spleen & $\begin{array}{l}\text { Macrophages, } \\
\text { erythrocytes, } \\
\text { neutrophils }\end{array}$ & +++ \\
\hline 14 & Skin & Macrophages & ++ \\
\hline 15 & Negative & - & - \\
\hline 16 & Spleen & Erythrocytes & + \\
\hline 17 & Negative & - & - \\
\hline 1 Control & Negative & - & - \\
\hline 2 Control & Negative & - & - \\
\hline 3 Control & Negative & - & - \\
\hline 4 Control & Negative & - & - \\
\hline 5 Control & Negative & - & - \\
\hline
\end{tabular}

prominent slime layer obscuring the underlying cell wall was present in numerous microorganisms (Fig. 5). These microorganisms were mainly localized free within cytoplasm, frequently surrounded by an adjacent clear zone (Fig. 6) and only rarely delimitated by a host cell membrane (Fig. 7). In the spleens, microorganisms were often detectable within erythrocytes and macrophages. Those observed within erythrocytes were included in a clear vacuole, rarely delimitated by a distinct cell membrane and did not possess a clear cell wall organization (Figs 8, 9), as observed in microorganisms present within skin macrophages or fibroblasts. Often, skin neutrophils, macrophages and fibroblasts containing the microorganisms showed degenerative changes, and sometimes, the infected cells were not recognizable due to severe degeneration. Degenerative changes consisted of widened and rarefied cytoplasm, containing electron-lucent material (oedema/cell swelling), swollen degenerated mitochondria, with partial loss of cristae (cristolysis), amorphous poorly electrondense flocculent debris and irregularly distended profiles of endoplasmic reticulum and nuclear envelope. Occasionally, plasma membrane disruption and blebbing were detectable. Neither microorganisms nor ultrastructural lesions were observed in any of the five RMS-free trout.

\section{Molecular biology}

Thirteen of 17 symptomatic trout $(76 \%)$ were positive for the presence of Rickettsiales by the

Figure 3 Skin. Transmission electron micrograph of a degenerated fibroblast with numerous microorganisms within the cytoplasm (Bar: $2 \mu \mathrm{m}$ ).

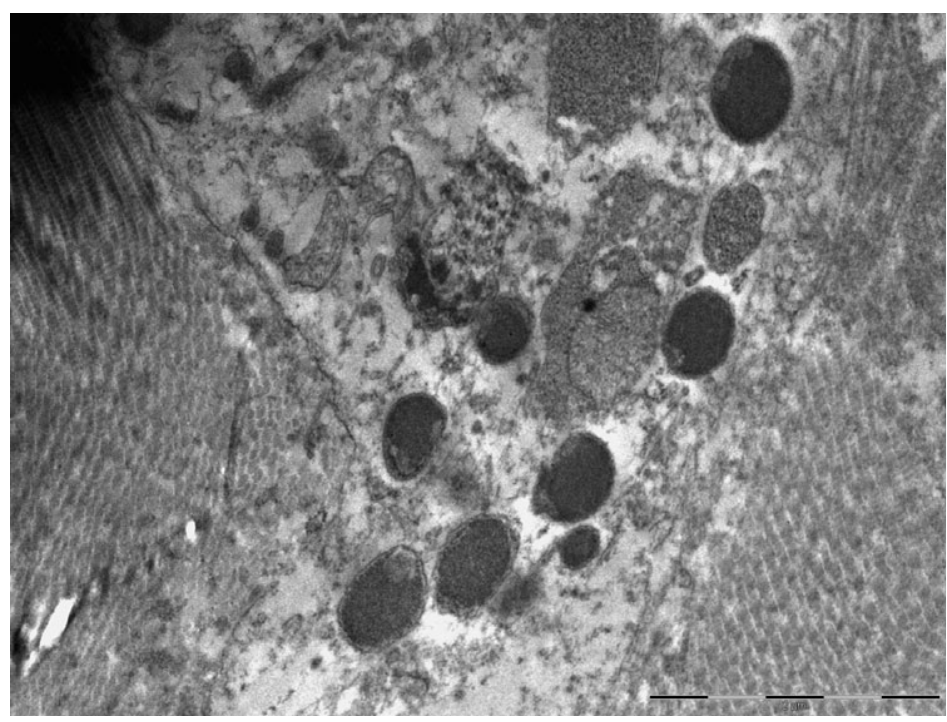





Figure 4 Magnification of Fig. 3. Some intracytoplasmic microorganisms with distinct inner and outer membrane (arrow heads) and thread-like structure (arrows) located at one pole of the bacterial body (arrows) (Bar: $500 \mathrm{~nm}$ ).

Figure 5 Skin. Degenerated mononuclear cell containing some microorganisms with distinct external slime layer (arrow heads) (Bar: $500 \mathrm{~nm}$ ).

nested PCR assay (Table 2). The primers RiFCfw-RiFCrev amplified a band of $188 \mathrm{bp}$ using as target an amplicon produced by the RLO1-RLO2 primers designed by Lloyd et al. (2008). No contamination was detected for the blanks used in the nested PCR steps. Only samples showing the expected band of $188 \mathrm{bp}$ by the second step of the nested PCR were considered positive. The specificity of the primers induces to restrict the identification to a Rickettsia-like organism or Midichloria-like organism. In seven trout, both skin and spleen were positive, and the remaining six trout were positive only in skin. All RMS-free trout samples were negative for RLO/ MLO DNA in nested PCR using RLO1/RLO2, as they did not produce any amplicon using RiFCfw-RiFCrev primers. The prevalence of positive RMS trout for MLO was 76\% with PCR and $59 \%$ with TEM. In skin samples, the prevalence was $76 \%$ with PCR and $41 \%$ with TEM, respectively. In spleen samples, the prevalence was $41 \%$ with PCR and $41 \%$ by TEM, respectively.

\section{Discussion}

Based on the approach proposed by Oidtmann et al. (2013) for the diagnostics of rainbow trout skin disorders, and by considering water temperature, clinical signs, gross lesions distribution and histopathological features, as reported in the 
Figure 6 Skin. Macrophage. Microorganism with trilaminar cell membrane included within host cell cytoplasm surrounded by an adjacent clear zone (Bar: $500 \mathrm{~nm}$ ).

Figure 7 Skin. Macrophage containing a microorganism included within a vacuole delimitated by a host cell membrane (Bar: $200 \mathrm{~nm})$.
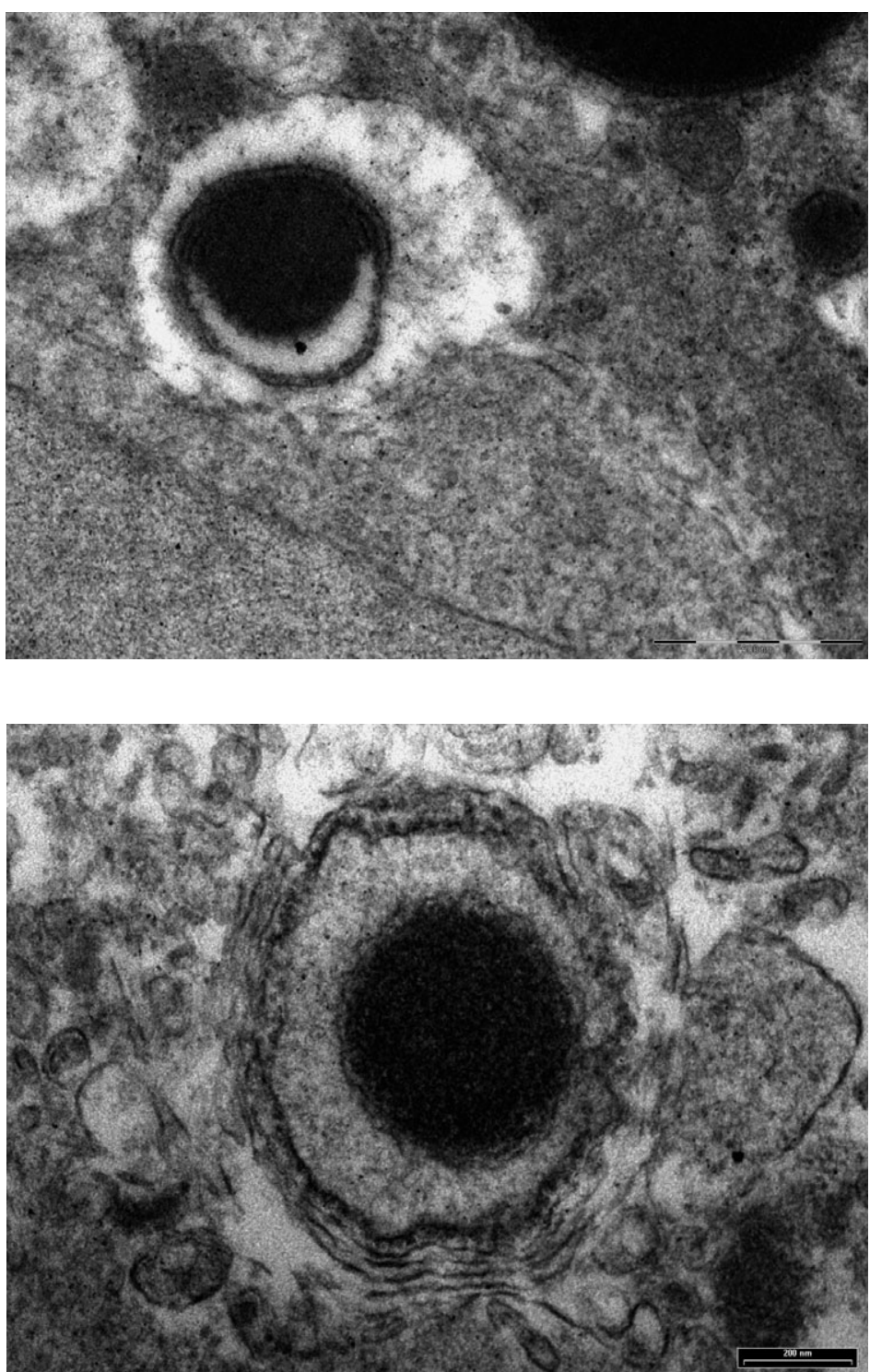

diagnostic tree for RMS/CWSD, it is possible to argue that the episodes under investigation can be referred as RMS.

The histological evaluation made it possible to describe a typical pattern of RMS lesions that was easily comparable to that already reported by several authors (Ferguson et al. 2006; Verner-Jeffreys et al. 2006; Noguera 2008; Schmidt-Posthaus et al. 2009; Galeotti et al. 2013b; Oidtmann et al. 2013; Kubilay et al. 2014).

Moreover, in this study, we integrated the histological approach with ultrastructural and biomolecular investigations, with the aim of supporting the identification of a potential etiological agent. In 10 of 17 trout investigated by TEM, ultrastructural observations revealed the presence of intracytoplasmic oval to short rod-shaped electron-dense microorganisms (400 to $800 \mathrm{~nm}$ in length and 100 to $200 \mathrm{~nm}$ in width) that often showed a typical cell wall organization of Gramnegative bacteria comparable to other ultramicroscopical descriptions of intracellular bacteria belonging to the order Rickettsiales (Silverman \& Wisseman 1978; Silverman 1991; Vannini et al. 2010; Vellaiswamy, Campagna \& Raoult 2011). These microorganisms were mainly localized free within host cell cytoplasm as observed by other authors for many Rickettsiales, including various Midichloria species or various Rickettsia species (Fritsche et al. 1999; Dumler et al. 2001; Duh 

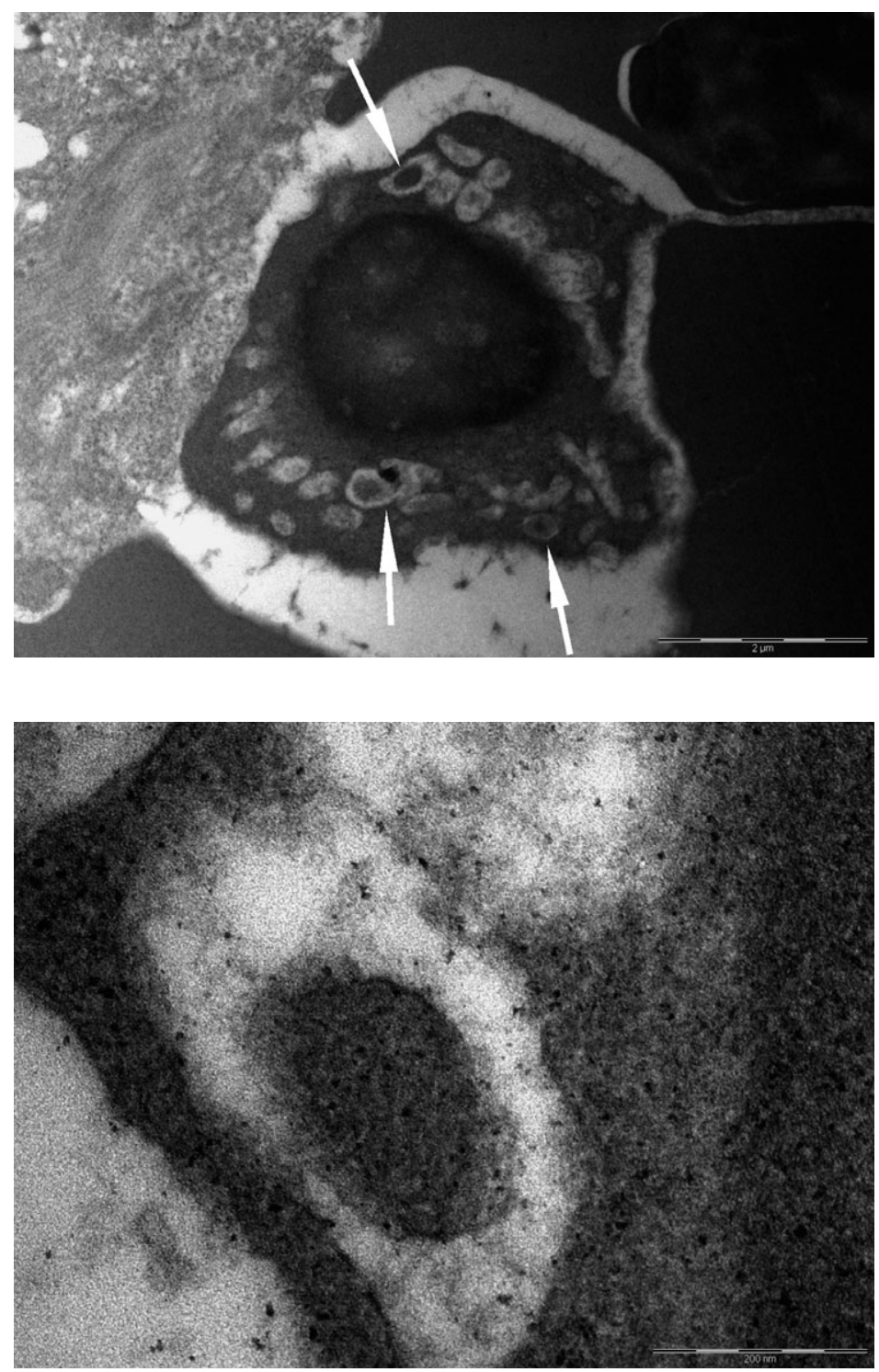

Figure 8 Spleen. Erythrocyte containing numerous microorganisms surrounded by a clear halo (arrows) (Bar: $2 \mu \mathrm{m}$ ). et al. 2010; Vannini et al. 2010; Szokoli et al. 2016). Silverman (1991) demonstrated by ultrastructural analysis that members of the genus Rickettsia exist free within the cytoplasm whereas Ehrlichia and Coxiella are bound by a phagosomal or phagolysosomal membrane. This concept has been reconfirmed by Dumler et al. (2001) and by Vannini et al. (2010). The absence of a hostderived membrane delimitating the bacteria is considered a peculiar morphological feature of the family Rickettsiaceae (Dumler et al. 2001; Vannini et al. 2010) whereas the ultrastructural descriptions of bacteria belonging to the new family Midichloriaceae within Rickettsiales order reported variable presence of a host membrane
(Sacchi et al. 2004; Sassera et al. 2006; Vannini et al. 2010; Szokoli et al. 2016). In our study, the microorganism observed sometimes showed an external slime layer as described in various Rickettsia species by Silverman et al. (1978) and also an intracellular thread-like structure was present, as observed by other authors (Wu \& Pan 1999; Nilsson et al. 2002). The bacteria within spleen erythrocytes did not display a distinct trilaminar cell wall as observed in the skin fibroblasts or macrophages. The meaning of this difference is not clear and might be related to a different phase of development (Kocan et al. 2004), with a different morphotype of the organism as described in Rickettsia prowazekii and Rickettsia rickettsii 
Table 2 Results of the TEM and PCR assay performed on the skin and spleen tissues from symptomatic and control trout using the RIFCfw-RIFCrev primers on the amplicons obtained by RLO1-RLO2 primers with the first-step PCR

\begin{tabular}{|c|c|c|c|c|c|c|c|}
\hline No. & Organs & TEM & $\begin{array}{l}\text { Second-step } \\
\text { PCR }\end{array}$ & No. & Organs & TEM & $\begin{array}{l}\text { Second-step } \\
\text { PCR }\end{array}$ \\
\hline \multirow[t]{2}{*}{1} & Skin & + & + & 12 & Skin & - & + \\
\hline & Spleen & np & + & & Spleen & - & - \\
\hline \multirow[t]{2}{*}{2} & Skin & + & + & 13 & Skin & + & + \\
\hline & Spleen & + & + & & Spleen & + & + \\
\hline \multirow[t]{2}{*}{3} & Skin & - & + & 14 & Skin & + & + \\
\hline & Spleen & + & - & & Spleen & + & + \\
\hline \multirow[t]{2}{*}{4} & Skin & + & + & 15 & Skin & - & - \\
\hline & Spleen & + & - & & Spleen & - & - \\
\hline \multirow[t]{2}{*}{5} & Skin & + & + & 16 & Skin & - & - \\
\hline & Spleen & - & + & & Spleen & + & - \\
\hline \multirow[t]{2}{*}{6} & Skin & - & + & 17 & Skin & - & - \\
\hline & Spleen & + & + & & Spleen & - & - \\
\hline \multirow[t]{2}{*}{7} & Skin & + & + & C & Skin & - & - \\
\hline & Spleen & - & + & & Spleen & - & - \\
\hline \multirow[t]{2}{*}{8} & Skin & - & + & C & Skin & - & - \\
\hline & Spleen & - & - & & Spleen & - & - \\
\hline \multirow[t]{2}{*}{9} & Skin & - & - & C & Skin & - & - \\
\hline & Spleen & - & - & & Spleen & - & - \\
\hline \multirow[t]{2}{*}{10} & Skin & - & + & C & Skin & - & - \\
\hline & Spleen & - & - & & Spleen & - & - \\
\hline \multirow[t]{2}{*}{11} & Skin & - & + & C & Skin & - & - \\
\hline & Spleen & - & - & & Spleen & - & _ \\
\hline
\end{tabular}

np, not performed; C, control.

(Silverman 1991), in Coxiella burnetti (McCaul \& Williams 1981) and in 'Candidatus Megaira polyxenophila' gen. nov., sp. nov. (Schrallhammer et al. 2013). Interestingly, the microorganisms we observed were detected in high numbers within the skin fibroblasts where the bacteria replication probably takes place, exploiting the proliferating stage of the fibroblast.

The data obtained by the molecular biology approach support the TEM findings. Indeed, 75\% of the positive samples by TEM were also positive for Rickettsiales using PCR. In fact, the primers RiFCfw-RiFCrev annealed both the Rickettsia-like organism 16S DNA sequence and the Midichloriaceae 16S DNA sequence (Midichloria-like organism, MLO) limiting the identification of the unculturable microorganism present in the fish tissues to Rickettsiales.

The presence of RLOs in trout with RMS has been previously suggested by some authors (Lloyd et al. 2008; Metselaar et al. 2010), and more recently in RMS trout farmed in Scotland, Midichloria-like organisms (MLO) have been detected by PCR (Cafiso et al. 2015). Recent phylogenetic studies described a new clade-family within Rickettsiales (Alphaproteobacteria), named Midichloriaceae, comprising several bacterial symbionts and the bacteria Midichloria mitochondri, a symbiont of the hard tick Ixodes ricinus (Sassera et al. 2006; Vannini et al. 2010). To date, the only ultrastructural study performed in RMS trout failed to reveal the presence of intralesional microorganisms (Verner-Jeffreys et al. 2008), whereas in the present investigation intracellular bacteria displaying ultrastructural features similar to bacteria belonging to Rickettsiaceae and Midichloriaceae families, order Rickettsiales, regarding shape, dimension, cell wall organization and subcellular localization, have been observed (Fritsche et al. 1999; Sacchi et al. 2004; Sassera et al. 2006; Vannini et al. 2010; Szokoli et al. 2016).

Some reports in the literature have associated RLO with fish infectious diseases (Chen et al. 1994, 2000; Corbeil, Hyatt \& Crane 2005). Most of these publications describe organisms close to Piscirickettsia salmonis, the causative agent of Piscirickettsiosis. This organism was erroneously considered a member of the Rickettsiaceae family, and in fact, phylogenetic studies confirmed the association of $P$. salmonis with the Gammaproteobacteria (Thiotrichales order) instead of Alphaproteobacteria (Fryer 2002; Fryer \& Hedrick 2003).

The ultrastructural features, combined with the results obtained by primers used in the second-step PCR, annealing to RLO and MLO 16S rRNA 
sequences, allow us to assume that TEM detected microorganisms belonging to the order Rickettsiales. The ultrastructural morphology of the microorganisms reported in this study represents the first description of intralesional intracellular prokaryotic Rickettsiales-like (Alphaproteobacteria) bacteria in RMS trout, as confirmed by PCR. Taken together, the data obtained provide a strong support for the role of a Rickettsiales-like organism in the etiology of RMS.

This conclusion leads us to the need for further studies aimed at obtaining unchallengeable proof of the etiological agent both through the isolation of the microorganism in cell lines and in vivo transmission trials. Other epidemiological aspects should be investigated, including the possible involvement of a specific vector harbouring Rickettsiales-like bacteria, in the spread of the disease.

\section{Acknowledgements}

The authors are grateful to Dr. Roberto Giavenni and Dr. Paolo Bronzatti for the help provided during field sampling. They also wish to thank Dr. Federico Rosso, Pierluigi Bagatella and Carla Calligaro, Department of Agricultural, Food, Environmental and Animal Science, Veterinary Pathology Section, University of Udine, for their valuable technical assistance.

\section{References}

Bruno D., Crumlish M., Lapatra S., Noguera P. \& VernerJeffreys D. (2007) Workshop on salmonid skin diseases. In: Proceedings 15th International Conference on Fish and Shellfish Diseases of the European Association of Fish Pathologists, Grado (Gorizia, Italy).

Cafiso A., Sassera D., Serra V., Bandi C., McCarthy U. \& Bazzocchi C. (2015) Molecular evidence for a bacterium of the family Midichloriaceae (order Rickettsiales) in skin and organs of the rainbow trout Oncorhynchus mykiss (Walbaum) affected by red mark syndrome. Journal of Fish Diseases 39, 497-501.

Chen S.-C., Tung M.-C., Chen S.-P., Tsai J.-F., Wang P.-C., Chen R.-S., Lin S.-C. \& Adams A. (1994) Systematic granulomas caused by a Rickettsia-like organism in Nile tilapia, Oreochronius niloticus (L.), from southern Taiwan. Journal of Fish Diseases 17, 591-599.

Chen S.-C., Wang P.-C., Tung M.-C., Thompson K.D. \& Adams A. (2000) A Piscirickettsia salmonis- like organism in grouper, Epinephelus melanostigma, in Taiwan. Journal of Fish Diseases 23, 415-418.

Corbeil S., Hyatt A.D. \& Crane M.S.J. (2005)

Characterisation of an emerging Rickettsia-like organism in
Tasmanian farmed Atlantic salmon Salmo salar. Diseases of Aquatic Organisms 64, 37-44.

Corpet F. (1988) Multiple sequence alignment with hierarchical clustering. Nucleic Acid Research 16, 10881-10890.

Duh D., Punda-Polic V., Avsic-Zupanc T., Bouyer D., Walker D.H., Popov V.L., Jelovsek M., Gracner M., Trilar T., Bradaric N., Kurtti T.J. \& Strus J. (2010) Rickettsia hoogstraalii sp. nov., isolated from hard and soft-bodied ticks. International Journal of Systematic and Evolutionary Microbiology 60, 977-984.

Dumler J.S., Barbet A.F., Bekker C.P.J., Dasch G.A., Palmer G.H., Ray S.C., Rikihisa Y. \& Rurangirwa F.R. (2001) Reorganization of genera in the families Rickettsiaceae and Anaplasmataceae in the order Rickettsiales: unification of some species of Ehrlichia with Anaplasma, Cowdria with Ehrlichia and Ehrlichia with Neorickettsia, descriptions of six new species combinations and designation of Ehrlichia equi and 'HE agent' as subjective synonyms of Ehrlichia phagocytophila. International Journal of Systematic and Evolutionary Microbiology 5, 2145-2165.

Ferguson H.W., Girons A., Rizgalla G., LaPatra S., Branson E.J., Mackenzie K., Davies M., Collins R.O., Diab A. \& Crumlish M. (2006) Strawberry disease in rainbow trout in Scotland: pathology and association with Flavobacterium psychrophilum. Veterinary Record 158, 630-632.

Fleury H.J.A., Vuillaume A. \& Sochon E. (1985) Isolation of an adeno-like virus from two cases of strawberry disease in rainbow trout. Annales de l'Institut Pasteur Virology 136, 223-228.

Fritsche T.R., Horn M., Seyedirashti S., Gautom R.K., Schleifer K.H. \& Wagner M. (1999) In situ detection of novel bacterial endosymbionts of Acanthamoeba spp. phylogenetically related to members of the order Rickettsiales. Applied and Environmental Microbiology 65 , 206-212.

Fryer J.L. (2002) Clarification of the systematics of Piscirickettsia salmonis. Fish Health Section Newsletter, American Fisheries Society 30, 23.

Fryer J.L. \& Hedrick R.P. (2003) Piscirickettsia salmonis: a Gram-negative intracellular bacterial pathogen of fish. Journal of Fish Diseases 26, 251-262.

Galeotti M., Giavenni R., Volpatti D., Beraldo P. \& Feist S.W. (2011) Red mark syndrome/cold water strawberry disease: emergence in Italy and histopathological investigations. In: Proceedings 15th International Conference of the European Association of Fish Pathologists, Split, Croatia.

Galeotti M., Beraldo P., Bulfon C., Vasilaki F., Mandrioli L., Sirri R., Sunyer O. \& Volpatti D. (2013a). Contribution on inflammation/cell proliferation markers to the study of RMS pathogenesis. In: Proceedings 17th International Conference of the European Association of Fish Pathologists, Tampere, Finland.

Galeotti M., Volpatti D., Beraldo P., Brunetti B., Galletti E. \& Feist S.W. (2013b) Red mark syndrome in rainbow trout (O. mykiss) farmed in Italy: anatomohistopathological investigations. Journal of Comparative Pathology 148, 54.

Kocan K.M., De La Fuente J., Blouin E.F. \& Garcia-Garcia J.C. (2004) Anaplasma marginale (Rickettsiales: 
Anaplasmataceae): recent advances in defining host-pathogen adaptations of a tick-borne rickettsia. Parasitology 129, S285-S300.

Kubilay A., Ciftci S., Yildirim P., Didinen I., Metin S., Demirkan T., Ozen M.R. \& Oidtmann B. (2014) First observation of red mark syndrome (RMS) in cultured rainbow trout (Oncorynchus mykiss Walbaum, 1972) in Turkey. Bulletin of European Association of Fish Pathologists 34, 95-101.

LaPatra S.E., Groff J.M., Lauda K.A., Munn B. \& Jones G.R. (1994) Dermatitides in cultured rainbow trout. In: Proceedings International Symposium on Aquatic Animal Health, September 4-8, 1994. Seattle, Washington.

Lloyd S.J., LaPatra S.E., Snekvik K.R., St-Hilaire S., Cain K.D. \& Call D.R. (2008) Strawberry disease lesions in rainbow trout from southern Idaho are associated with DNA from a Rickettsia-like organism. Diseases of Aquatic Organisms 82, 111-118.

McCaul T.F. \& Williams J.C. (1981) Developmental cycle of Coxiella burnetii: structure and morphogenesis of vegetative and sporogenic differentiations. Journal of Bacteriology 147, 1063-1076.

Metselaar M., Thompson K.D., Gratacap R.M.L., Kik M.J.L., LaPatra S.E., Lloyd S.J., Call D.R., Smith P.D. \& Adams A. (2010) Association of red-mark syndrome with a Rickettsia-like organism and its connection with strawberry disease in the USA. Journal of Fish Diseases 33, 849-858.

Nilsson K., Påhlson C., Lukinius A., Eriksson L., Nilsson L. \& Lindquist O. (2002) Presence of Rickettsia helvetica in granulomatous tissue from patients with sarcoidosis. The Journal of Infectious Disease 185, 1128-1138.

Noguera P. (2008) Red mark syndrome (RMS). Fish Farmer $31,38$.

Oidtmann B. \& Noguera P. (2008) Red mark syndrome/cold water strawberry disease- epidemiological study. Finfish News 6, $10-11$.

Oidtmann B., LaPatra S.E., Verner-Jeffreys D., Pond M., Peeler E.J., Noguera P.A., Galeotti M. \& Feist S.W. (2013) Differential characterization of emerging skin diseases of rainbow trout - a standardized approach to capturing disease characteristics and development of case definitions. Journal of Fish Diseases 36, 921-937.

Olson D.P., Beleau M.H., Busch R.A., Roberts S. \& Krieger R.I. (1985) Strawberry disease in rainbow trout, Salmo gairdneri Richardson. Journal of Fish Diseases 8, 103-111.

Sacchi L., Bigliardi E., Corona S., Beninati T., Lo N. \& Franceschi A. (2004) A symbiont of the tick Ixodes ricinus invades and consumes mitochondria in a mode similar to that of the parasitic bacterium Bdellovibrio bacteriovorus. Tissue and Cell 36, 43-53.

Sasani F., Shokrpoor S., Rahmati-Holasoo H. \& Zargar A. (2016) Appearance of red mark syndrome (RMS) in cultured rainbow trout (Oncorynchus mykiss Walbaum, 1972) in Iran. Bulletin of European Association of Fish Pathologists 36, 90-94.

Sassera D., Beninati T., Bandi C., Bouman E.A.P., Sacchi L., Fabbi M. \& Lo N. (2006) "Candidatus Midichloria mitochondri" an endosymbiont of the tick Ixodes ricinus with a unique intramitochondrial lifestyle. International Journal of Systematic and Evolutionary Microbiology 56, 2535-2540.

Schmidt-Posthaus H., Bergmann W., Knüsel R., Heistinger H. \& Licek E. (2009) Appearance of red mark syndrome/cold water strawberry disease in Switzerland and Austria. Diseases of Aquatic Organisms 88, 65-68.

Schrallhammer M., Ferrantini F., Vannini C., Galati S., Schweikert M., Görtz H.D., Verni F. \& Petroni G. (2013) 'Candidatus Megaira polyxenophila' gen. nov., sp. nov.: considerations on evolutionary history, host range and shift of early divergent Rickettsiae. PLoS ONE 8, e72581.

Silverman D.J. (1991) Some contributions of electron microscopy to the study of the Rickettsiae. European Journal of Epidemiology 7, 200-206.

Silverman D.J. \& Wisseman C.L. Jr (1978) Comparative ultrastructural study on the cell envelopes of Rickettsia prowazekii, Rickettsia rickettsii and Rickettsia tsutsugamushi. Infection and Immunity 21, 1020-1023.

Silverman D.J., Wisseman C.L. Jr, Waddell A.D. \& Jones M. (1978) External layers of Rickettsia prowazekii and Rickettsia rickettsia: occurrence of a slime layer. Infection and Immunity 22, 233-246.

St-Hilaire S. \& Jeffery K. (2004) Strawberry disease in rainbow trout. Trout News 37, 24.

Szokoli F., Sabaneyeva E., Castelli M., Krenek S., Schrallhammer M., Soares C.A.G., da Silva-Neto I.D., Berendonk U. \& Petroni G. (2016) "Candidatus Fokinia solitaria", a novel "Stand-Alone" symbiotic lineage of Midichloriaceae (Rickettsiales). PLoS One. doi: 10.1371/ journal.pone.0145743 January 5.

Vannini C., Ferrantini F., Schleifer K.H., Ludwig W., Verni F. \& Petroni G. (2010) "Candidatus Anadelfobacter veles" and "Candidatus Cytrobacter comes", two new Rickettsiales species hosted by the protist cliate Euplotes harpa (Ciliophora, Spirotrichea). Applied and Environmental Microbiology 76, 4047-4054.

Vellaiswamy M., Campagna B. \& Raoult D. (2011) Transmission electron microscopy as a tool for exploring bacterial proteins: model of RickA in Rickettsia conorii. New Microbiologica 34, 209-218.

Verner-Jeffreys D., Algoet M., Feist S., Bateman K., Peeler E. \& Branson E. (2006) Studies on red mark syndrome. Finfish News 1, 19-22.

Verner-Jeffreys D.W., Pond M.J., Peeler E.J., Rimmer G.S.E., Oidtmann B., Way K., Mewett J., Jeffrey K., Bateman K., Reese R.A. \& Feist S.W. (2008) Emergence of cold water strawberry disease of rainbow trout Oncorynchus mykiss in England and Wales: outbreak investigations and transmission studies. Diseases of Aquatic Organisms 79, 207-218.

Wu X. \& Pan J. (1999) Studies on Rickettsia-like organism disease of the tropical marine pearl oyster I: the fine structure and morphogenesis of Pinctada maxima pathogen Rickettsialike organism. Journal of Invertebrate Pathology 73, 162-172.

Received: 24 May 2016

Revision received: 21 September 2016

Accepted: 22 September 2016 